\title{
SL 材の不具合の予測方法の枠組みの提示
}

SL 材の不具合からみたコンクリート床下地の表層部品質の評価方法（その 3 ）

\section{OUTLINE OF DEFECT PREDICTION METHOD FOR SELF-LEVELING MATERIAL}

Evaluation method about surface layer quality of concrete floor groundwork corresponding to defect in self-leveling material (Part 3)

横山裕*1, 金 兒 鎬*2, 横井 健*3, 崔 寿 炅*4

Yutaka YOKOYAMA, Doo Ho KIM, Takeshi YOKOI and Soo Kyung CHOI

\begin{abstract}
Relations between defects in self-leveling material and surface quality of concrete slab were experimentally examined. A defect occurrence situation was changed greatly by condition of slab surface. Then, situations were classified into three kinds, "No defect", "Separation" and "Crack". Moreover, it became clear that defect occurrence situation can be predicted by amount of surface moisture and volume of micro voids. Then, when cracks may be occur, amount of cracks can be predicted by surface strength. Those measurements can be easily done in actual construction sites. Therefore, this defect prediction method greatly contributes to performance gain of floors.
\end{abstract}

Keywords : self-leveling material, separation, crack, concrete floor groundwork, surface quality, evaluation method セルフレベリング材, 剥離, ひび割れ，コンクリート床下地，表層部品質，評価方法

\section{1.はじめに}

近年、コンクリート床下地 (以降、単に“床下地”と記す)上に比 較的流動性が高いスラリー状の材料で自己平坦性があるセルフレベ リング材 (以降、“SL材” と記す)を施工寸る工法が、様々な用途の 建築物の新筑, 改修工事で採用されるようになってきたが、それに ともない、施工後のひび割れや床下地との剥離などの不具合が発生 する事例が多く報告されるようになってきている。SL材の不具合に は、SL材の特性や施工条件などとともに、床下地の表層部品質が大 きく影響していると想定される。したがって、不具合の発生を未然 に防ぐためには、SL材施工前に床下地の表層部品質を測定，評価し、 施工後に発生する不具合を予測できる枠組みを確立する必要がある。

筆者らは、この枠組みの確立を最終的な目的とした研究の基礎的 段階上して、前報(その 1)1)では、床下地試験体にSL材を施工し、 発生する不具合の経時変化や陚験体の大きさが不具合におよぼす影 響などについて検討した。さらに、前報(その2 2) では、SL材を使 用寸る例が比較的多い高強度コンクリート製の床下地を対象に、表 層部に関する品質項目の1つである表面強度とひび割れの関倸を定量 的に検討した。

本報は、より多くの種類のコンクリートを対象に、表面強度以外 の項目も含む様々な床下地の表層部品質とSL材に発生する不具合と の関係を実験的に検討し、種々の床下地に共通に適用できる不具合 の予測方法の枠組みを提示した経過，結果を述べるものである。

\section{2. 研究目的, 範囲}

前報(その 2)では、高強度コンクリート製の床下地を対象上した
検討を行った。これは、フレッシュコンクリートの状態での特性が 通常のコンクリート上大をく異なり、床スラブに使用した場合土間 工の「ならし」，「仕上げ」などの上面仕上げ作業がしにくいため、所 定の精度を確保する目的でSL材を使用する例が比較的多いことによ る。一方、集合住宅なよ゙では、使用者の精度に対寸る要求が近年ま すます高まっていることから、床下地に用いるコンクリートの種類 のいかんに関わらずSL材を用いる事例が多くなってきている。また、 既存建築物の改修工事などの際には、使用されているコンクリート の材料, 調合および施工条件やその後の使用状況などが明らかでな い床下地にSL材を施工しなければならない場合も多々あると思われ る。すなわち、SL材の不具合の予測方法は、床下地のコンクリート の種類などのいかんに関わらず適用できる方法であることが望まし い。よって本報では、対象とする床下地のコンクリートの種類を特 に限定せず、表層部品質を共通の手順で測定, 評価し、SL材の不具 合を予測する方法の枠組みを提示することを目的とする。

なお、前報（その 1 ) および(その 2 ) と同様、具体的なコンクリー トの材料, 調合や床下地の施工条件などと表層部品質との関係の検 討、あるいはコンクリートの材料, 調合や床下地の施工条件など之 SL材の不具合との関倸の検討は、本研究の範囲外々寸る。また、本 報は枠組みの提示を目的としているので、対象とするSL材の種類お よび塗り厚などは代表的な 1 種とし、当該SL材に規定された方法で 施工寸ることとする。なお、SL材の種類および塗り厚などを多様に した検討は、本報で提示される枠組みを適用することによる次報以 降の課題上する。

\footnotetext{
*1 東京工業大学大学院理工学研究科建築学専攻 准教授・工博

*2 当時 東京工業大学大学院理工学研究科建築学専攻

博士 (工学)

${ }^{* 3}$ 東海大学工学部建築学科 講師・博士 (工学)

*4 韓瑞大学校工学部建築工学科 副教授・博士 (工学)
}

Assoc. Prof., Dept. of Architecture and Building Eng., Graduate School of Science and Eng., Tokyo Institute of Technology, Dr. Eng. Graduate School, Tokyo Institute of Technology, Dr. Eng. Junior Assoc. Prof., Dept. of Architecture and Building Eng., School of Eng., Tokai
University, Dr. Eng.

Assoc. Prof., Dept. of Architectural Eng., Faculty of Eng., Hanseo Univ., Dr. Eng. 


\section{3. 既往の研究}

前報(その1)で述べた通り、SL材に関する研究例は非常に少なく、 SL材のひび割れや剥離、およびこれらと床下地との関倸などを対象 とした研究例は、前報（その1），(その2）以外にみあたらない。

前報(その 1 ) では、数種のコンクリートを用い、大きさの異なる 数段階の床下地試験体を作成したうえで、各試験体上にSL材を施工 し、不具合の発生状況や経時変化を観察するとともに、試験体の大 きさの影響などについて検討した。その結果、以下に示寸知見が得 られた。

・SL材の不具合の発生状況は、床下地により大きく異なった。一 部の試験体では、SL材施工後比較的早い段階(施工後 1 週程度以 内と思われる)で試験体周囲から剥離が発生した(以降、この剥離 を“早期剥離”と記す)。この原因の1つとして、他の試験体と比 較して、床下地表層部に含まれる水分量が大きいことが推察され た。一方、早期剥離が発生しなかった試験体では、その後ひび割 れが発生し、さらにひび割れの成長にともない幅の大きいひび割 れに沿って剥離が発生した。

・ひび割れの経時変化を観察したところ、ひび割れは施工4週後程 度までに発生し、以降12週後程度までは発生したひび割れの幅が 増加寸る傾向がみられた。すなわち、SL材のひび割れについて 検討寸る場合、SL材施工後、仕上げを施さない状態のまま、ひび 割れ幅の増加がほぼみられなくなるまで記録, 測定を継続するの が適当と考えられた。また、ひび割れの程度を表寸指標としては 「ひび割れ長さメ幅」を用いるのが、現段階では適当と考えられた。

・床下地の表面凹凸が極端に大きく、SL材の塗り厚が著しく薄い (厚い)部分や涂り厚の変化が著しく大きい部分がある試験体で は、その部分からひび割れが発生した。

· 大きさの異なる3段階の試験体 $(600 \times 2700 \mathrm{~mm}, 600 \times 1200 \mathrm{~mm}, 600$ $\times 600 \mathrm{~mm})$ で、ひび割れや剥離の発生状況に大きな違いはみられな かった。すなわち、少なくともこの範囲内では、試験体の大きさ はひび割れや剥離に大きくは影響しないとみなすことができた。 さらに、前報(その 2 ) では、SL材の施工例の多い高強度コンクリー 卜製床下地を対象に、水分量の影響が現れないよう留意して準備し た試験体を用いて、ひび割れと、ひび割れに大きく影響する品質項 目の1つと思われる表面強度との関係を倹討した。その結果、以下に 示す知見が得られた。

・ 床下地試験体の表面強度を、日本建築仕上学会式引つかき試験器 法, 建研式接着力試験器法、および筆者らが考案したせん断強度 試験器を用いる方法の3種の方法で測定し、相互の関係を検討し た。その結果、3種の方法による測定結果には互いに高い相関が みられた。

・高強度コンクリート製床下地の表面強度は、普通コンクリートと 比較して必ずしも大きいとは限らず、むしろ大きくは異ならない 場合が多い。

・いずれの試験体でも早期剥離は発生せず、ひび割れが発生した。 ひび割れの経時変化の傾向は、前報(その1) と同様であった。

・ひび割れの経時変化と、別途測定したSL材の収縮率の経時変化 は、同様の傾向を示した。すなわち、SL材の収縮とひび割れの 発生，成長には因果関係があることがらかがえた。

・SL材のひび割れ長さ×幅と床下地の表面強度には高い相関が女
り、表面強度が小さいほどひび割れの程度が大きくなる傾向がみ られた。

本報では、以上の知見を参考に、対象と寸るコンクリートの種類 上表層部の品質項目を多様にした検討を行うこととした。

\section{4. 研究方法}

本報における研究方法，手順は、以下の通りである。

(1) コンクリートの材料, 調合や作製時の施工条件などが異なる、種々 の床下地試験体を作製する。

(2) (1)で作製した試験体を対象に、種々の表層部品質を測定する。

(3) (2)で表層部品質を測定した試験体上に、SL材を施工する。

(4) (3)で施工したSL材のひび割れ，剥離の発生状況を定期的に記録 すると々もに、ひび割れの長さ，幅を測定する。記録，測定は、 ひび割れ, 剥離の発生, 成長がほぼ止まったとみなせる時点まで 継続する。

(5) (2)で測定した表層部品質と、(4)で記録，測定したひび割れ，剥離 の関係を検討する。

(6) (5)の検討結果に基づき、SL材の不具合の予測方法の朹組みを提 示する。

なお、(1)〜(5)の実験は、いずれも温度 $20^{\circ} \mathrm{C}$ ，相対湿度 $50 \%$ の恒温 恒湿実験室で行う。

\section{5. 床下地試験体の作製 \\ 5.1. 試験体の概要}

図1に、試験体の概要を示す。本試験体は、スラブ厚150m地上端 と下端に格子状配筋 (D10@150mm, かぶり厚 $30 \mathrm{~mm}$ )が施された、一般 的な構造スラブの一部を模擬したものである。試験体の大きさは前 報（その 1 )の結果を参考に $600 \times 800 \mathrm{~mm}$ とし、このうち $600 \times 600 \mathrm{~mm}$ の 部分にSL材を施工寸ることとした。また、残りの $600 \times 200 \mathrm{~mm}$ の部分 は、表層部品質の測定に供することとした。

なお、本報では、新規に作成寸る試験体のほかに、既往の研究 ${ }^{3)}$ で筆者らが作製し実験終了後8〜10ヶ月間保管していた試験体も用い ることとした。以降、前者を“新規試験体”、後者を“既存試験体” と記すこととする。

\section{2. コンクリートおよび施工条件の概要}

表1に、試験体に用いたコンクリートの材料(セメント，混和凰）， 調合および作製時の施工条件なよ゙を示寸。コンクリートは、実際の 現場で床下地施工に用いられている様々なコンクリートの材料, 調 合、および上面仕上げ作業時の養生剂散布の有無などについて調查 した結果4などを参考に、強度，材料，流動性などが多様な試験体 群となるよう留意して選定したものである。また、施工条件は、実

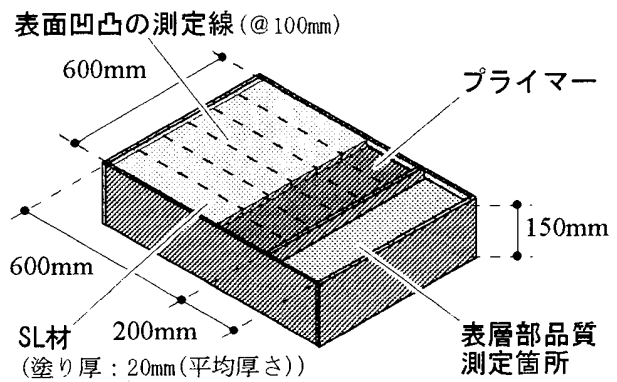

図1試験体の概要 
表1 コンクリートの材料，調合および作製時の施工条件と不具合の発生状況

\begin{tabular}{|c|c|c|c|c|c|c|c|c|c|c|c|}
\hline 試 & & & & & & & 調合 & & & & \\
\hline 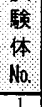 & 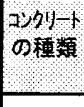 & 分疑 & & $\begin{array}{l}\text { 叫U } \\
\text { 强度 }\end{array}$ & $\begin{array}{r}\text { またたは } \\
\text { スラププ- } \\
(\mathrm{cm})\end{array}$ & 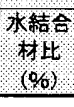 & $\begin{array}{l}\text { 細贯 } \\
\text { 材率 } \\
(\%) \\
\end{array}$ & 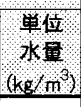 & 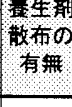 & 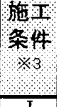 & 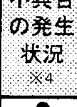 \\
\hline \begin{tabular}{|l|l}
$\frac{1}{2}$ \\
3 \\
\end{tabular} & 普通 & $\mathrm{N}$ & 普 & 18 & $\mathrm{SL}=18$ & 65 & 48 & 179 & 無 & \begin{tabular}{|c|} 
I \\
II \\
III \\
\end{tabular} & $\div$ \\
\hline \begin{tabular}{|l|}
4 \\
5 \\
6 \\
\end{tabular} & 普通 & $\mathrm{N}$ & 普 & 18 & $\mathrm{SL}=21$ & 65 & 50 & 189 & 無 & \begin{tabular}{|c|} 
I \\
II \\
III \\
\end{tabular} & $\frac{0}{0}$ \\
\hline $\begin{array}{l}7 \\
8 \\
9 \\
\end{array}$ & 普通 & $\mathrm{N}$ & 普 & 21 & $\mathrm{SL}=18$ & 65 & 48 & 170 & 無 & \begin{tabular}{|c|} 
I \\
II \\
III \\
\end{tabular} & $\begin{array}{l}0 \\
0 \\
0\end{array}$ \\
\hline$\frac{10}{11}$ & 普通 & $\mathrm{N}$ & 普 & 27 & $\mathrm{SL}=8$ & 55 & 42 & 158 & 無 & \begin{tabular}{|c|} 
I \\
II \\
III \\
\end{tabular} & $\bullet$ \\
\hline $\begin{array}{l}13 \\
14 \\
15 \\
\end{array}$ & 普通 & $\mathrm{N}$ & 普 & 27 & $\mathrm{SL}=8$ & 55 & 46 & 158 & 無 & \begin{tabular}{|c|} 
I \\
II \\
III
\end{tabular} & $\div$ \\
\hline $\begin{array}{l}\frac{16}{17} \\
18 \\
\end{array}$ & 普通 & $\mathrm{N}$ & 普 & 27 & $\mathrm{SL}=15$ & 55 & 45 & 170 & 無 & \begin{tabular}{|c} 
I \\
II \\
III \\
\end{tabular} & $\frac{1}{2}$ \\
\hline $\begin{array}{l}\frac{19}{20} \\
21 \\
\end{array}$ & 普通 & $\mathrm{N}$ & 普 & 27 & $\mathrm{SL}=15$ & 55 & 43 & 171 & 無 & \begin{tabular}{|c|} 
I \\
II \\
III \\
\end{tabular} & $\div$ \\
\hline $\begin{array}{l}22 \\
23 \\
24 \\
\end{array}$ & 普通 & $\mathrm{N}$ & 普 & 27 & $S L=18$ & 55 & 45 & 182 & 無 & \begin{tabular}{|l} 
I \\
II \\
III
\end{tabular} & $\div$ \\
\hline$\frac{25}{26}$ & 普通 & $\mathrm{N}$ & 普 & 27 & $S L=18$ & 55 & 46 & 185 & 無 & \begin{tabular}{|l} 
I \\
II \\
III
\end{tabular} & $\begin{array}{l}\bullet \\
0 \\
-\end{array}$ \\
\hline $\begin{array}{l}28 \\
29 \\
30 \\
\end{array}$ & 普通 & $\mathrm{N}$ & 普 & 27 & $\mathrm{SL}=21$ & 55 & 47 & 193 & 無 & $\frac{\text { I }}{- \text { II }}$ & $\frac{1}{0}$ \\
\hline $\begin{array}{l}31 \\
32 \\
33 \\
\end{array}$ & 普通 & $\mathrm{N}$ & 普 & 31 & $\mathrm{SL}=8$ & 47 & 41 & 161 & 無 & $\begin{array}{c}\text { I } \\
\text { II } \\
\text { III }\end{array}$ & 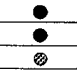 \\
\hline $\begin{array}{l}34 \\
35 \\
36 \\
\end{array}$ & 普通 & $\mathrm{N}$ & 普 & 31 & $\mathrm{SL}=15$ & 47 & 41 & 177 & 無 & $\begin{array}{c}\text { I } \\
\text { II } \\
\text { III }\end{array}$ & $\because$ \\
\hline $\begin{array}{l}37 \\
38 \\
39 \\
\end{array}$ & 普通 & $\mathrm{N}$ & 普 & 31 & $\mathrm{SL}=18$ & 47 & 41. & 188 & 無 & \begin{tabular}{|c|} 
I \\
II \\
III \\
\end{tabular} & $\because$ \\
\hline $\begin{array}{l}40 \\
41 \\
42 \\
\end{array}$ & 普通 & $\mathrm{N}$ & 普 & 31 & $\mathrm{SL}=21$ & 47 & 45 & 199 & 無 & \begin{tabular}{|c|} 
I \\
II \\
III \\
\end{tabular} & $\ddot{\circ}$ \\
\hline $\begin{array}{l}43 \\
44 \\
45 \\
\end{array}$ & 普通 & $\mathrm{N}$ & 普 & 35 & $\mathrm{SL}=8$ & 40 & 37 & 166 & 無 & \begin{tabular}{|l|} 
I \\
II \\
In \\
\end{tabular} & $\div$ \\
\hline $\begin{array}{l}46 \\
47 \\
48 \\
9\end{array}$ & 普通 & $\mathrm{N}$ & 普 & 35 & $S L=15$ & 40 & 38 & 184 & 無 & \begin{tabular}{|l|} 
I \\
II \\
III \\
\end{tabular} & $\div$ \\
\hline $\begin{array}{l}49 \\
50 \\
51 \\
\end{array}$ & 普通 & $\mathrm{N}$ & 普 & 35 & $\mathrm{SL}=18$ & 40 & 39 & 195 & 無 & \begin{tabular}{|c|} 
I \\
II \\
III \\
\end{tabular} & $\div$ \\
\hline $\begin{array}{l}\frac{52}{53} \\
54 \\
5\end{array}$ & 普通 & $\mathrm{N}$ & 普 & 35 & $\mathrm{SL}=21$ & 40 & 41 & 206 & 無 & \begin{tabular}{|c|} 
I \\
II \\
III \\
\end{tabular} & $\div$ \\
\hline $\begin{array}{l}55 \\
56 \\
57 \\
5\end{array}$ & $\begin{array}{l}\text { 高強度 } \\
\text { 高流動 }\end{array}$ & $M$ & 高 & 58 & $\mathrm{SLF}=70$ & 31 & 49 & 165 & 無 & \begin{tabular}{|l|} 
I \\
II \\
III
\end{tabular} & $\begin{array}{l}0 \\
0 \\
0\end{array}$ \\
\hline $\begin{array}{l}58 \\
59 \\
60 \\
\end{array}$ & $\begin{array}{l}\text { 高強度 } \\
\text { 高流動 }\end{array}$ & M & 高 & 58 & $\mathrm{SLF}=70$ & 31 & 49 & 165 & 有 ${ }^{* 2}$ & \begin{tabular}{|l} 
I \\
II \\
III
\end{tabular} & $\begin{array}{l}0 \\
0 \\
0\end{array}$ \\
\hline $\begin{array}{l}\frac{61}{62} \\
63 \\
63\end{array}$ & $\begin{array}{l}\text { 高強度 } \\
\text { 高流䖝 }\end{array}$ & L & 高 & 67 & $\mathrm{SLF}=70$ & 27 & 48 & 165 & 有 F2 $^{2}$ & \begin{tabular}{|l} 
I \\
II \\
III \\
\end{tabular} & 0. \\
\hline $\begin{array}{l}64 \\
65 \\
66 \\
\end{array}$ & $\begin{array}{l}\text { 高強度 } \\
\text { 高流動 }\end{array}$ & M & 高 & 80 & $\mathrm{SLF}=80$ & 24 & 46 & 165 & 有 *2 $^{2}$ & \begin{tabular}{|c|} 
I \\
II \\
III \\
I
\end{tabular} & $\begin{array}{l}0 \\
0 \\
0 \\
\end{array}$ \\
\hline $\begin{array}{r}-67 \\
689 \\
69 \\
\end{array}$ & $\begin{array}{l}\text { 高強度 } \\
\text { 高流動 }\end{array}$ & SF & 超 & 108 & $\mathrm{SLF}=60$ & 19 & 43 & 155 & 有 ${ }^{* 2}$ & $\begin{array}{l}\text { I } \\
\text { II } \\
\text { III } \\
\end{array}$ & \\
\hline $\begin{array}{l}71 \\
72 \\
73 \\
\end{array}$ & 普通 & $\mathrm{N}$ & 普 & 27 & $\mathrm{SL}=8$ & 55 & 46 & 158 & 無 & \begin{tabular}{r|} 
I \\
II \\
$\mathrm{II}$ \\
$\mathrm{IV}$ \\
\end{tabular} & $\begin{array}{l}0 \\
0 \\
0 \\
0\end{array}$ \\
\hline $\begin{array}{l}74 \\
75 \\
76 \\
77 \\
\end{array}$ & 普通 & $\mathrm{N}$ & 普 & 27 & $S L=18$ & 55 & 46 & 185 & 無 & $\begin{array}{l}\text { I } \\
\text { II } \\
\text { III } \\
\text { IV } \\
\end{array}$ & $\begin{array}{l}0 \\
0 \\
2 \\
2\end{array}$ \\
\hline$\frac{78}{79}$ & 普通 & $\mathrm{N}$ & 普 & 27 & $S L=18$ & 55 & 46 & 185 & 無 & I I & 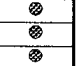 \\
\hline
\end{tabular}

※1:使用したセメント，混和材料の種類による分類

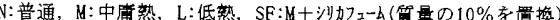

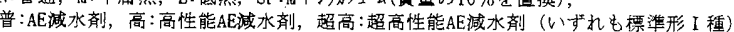

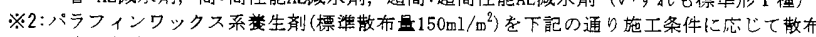

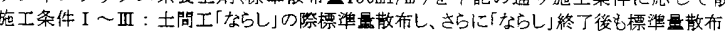

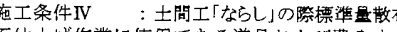

※3:上面仕上げ作業に使用できる道具抽よび費やすことのできる作業時䦓などの条件

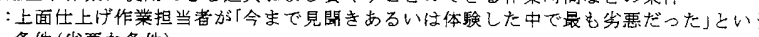
条件 (劣覀な条件)

II：上面仕上げ作業担当者拉よび施工管理担当者が「最近ではこの程度が一般的だ」という 条件 (一般的な条件)

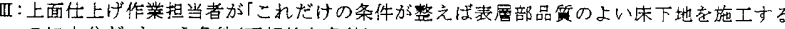
のに十分だ」といら条件(理想的な条件)

$\mathrm{N}$ ：上面仕上げ作業のらち土間工のならしまでは施工条件口乞同様の条件で实施するが 在上げは实施しない条件

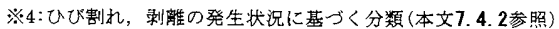

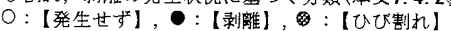

際の現場における床下地の施工条件(フレッシュコンクリートの投入 速度, ポンプ1台あたりの作業人員数, 作業員 1 人あたりの担当面積, 作業手順, 使用寸る道具など)の実状調査結果 ${ }^{5}$ に基づいて設定した ものである。各施工条件の意味は、表1に示す通りである。なお、各 施工条件の具体的な内容については、既往の研究5)で述べている。

\section{3. 試験体の作製}

\subsection{1 新規試験体}

表1に示すNo.1〜69の試験体は、2006年1月および6月に作製した。 具体的には、所定の材料，調合で混練したコンクリートを型枠に打 設し、所定の施工条件にしたがって上面仕上げを施して完成させた。 上面仕上げ作業は、熟練した上面仕上げ作業担当者の指導のもと、 日常は上面仕上げ作業に従事していない者が行った。特に、床下地 の表層部品質に大きく影響するならし，仕上げ作業は、作業者の違 いによる影響を排除寸る目的で、全て同一の者が行った。

試験体は、コンクリート打設後 4 週以上気中養生(施工条件 III の場 合は打設直後の3日間湿潤養生のうえ気中養生)した。

\subsection{2 既存試験体}

表1に示すNo.70〜800試験体は、既往の研究3で筆者らが作製し た試験体を用いた。これらの試験体は、フレッシュコンクリートの 特性および床下地の施工条件と床下地の表面凹凸との関倸を検討寸 る目的で、材料, 調合および施工条件を種々変化させて作製したも のである。作製時の試験体の大きさは $600 \times 2700 \mathrm{~mm}$ であるが、本報で は、試験体の中央部を $600 \times 800 \mathrm{~mm}$ に切断して用いた。

なお、既存試験体のなかには材料，調合および施工条件が他の試 験体と同一のものもあるが、既存試験体では保管時の環境条件など を厳密に管理していなかったことから、材料，調合および施工条件 が同一であっても表層部品質の観点からそれぞれ別個の試験体とみ なせるものである。

\section{6. 床下地の表層部品質の測定}

\section{1. 測定概要}

測定する品質項目は、床下地上に仕上げ材を接着あるいは塗装す る構法の床での不具合の原因として床施工に携わる多くの関係者か， ら指摘されている6)、表面強度, 表層部の水分量および表層部の密 実性とした。また、前報(その1)の結果、表面凹凸が極端に大きく SL材の塗り厚が著しく薄い(厚い)部分や塗り厚の変化が著しく大き い部分がある床下地では、その部分にひび割れが発生することが明 らかとなったことから、このような試験体がないことを確認寸る目 的で、表面凹凸も測定することとした。

以下に、測定項目ごとに、具体的な測定方法の概要を述べる。

\section{I 表面強度}

\section{（1）引っかき傢幅}

日本床施工技術研究協議会注1)が提案した「コンクリート床下地表 層部の諸品質の測定方法，グレードB)」に、表面強度の測定方法上し て規定された方法。日本建築仕上学会式引っかき試験器 $(1.0 \mathrm{kgf} の$ 荷 重が常にかかる先端角 $90^{\circ}$ のタンガロイ鋼製尖りピンにより引っかき 傷を付ける装置)を用いて床下地表面に引っかき傷を付け、その傷幅 を測定する。傷幅が小さいほど、表面強度が大きいことを表す。

\section{(2) 引張強度}

建研式接着力試験器を用いる方法。 $40 \times 40 \mathrm{~mm}$ の鋼製アタッチメン 


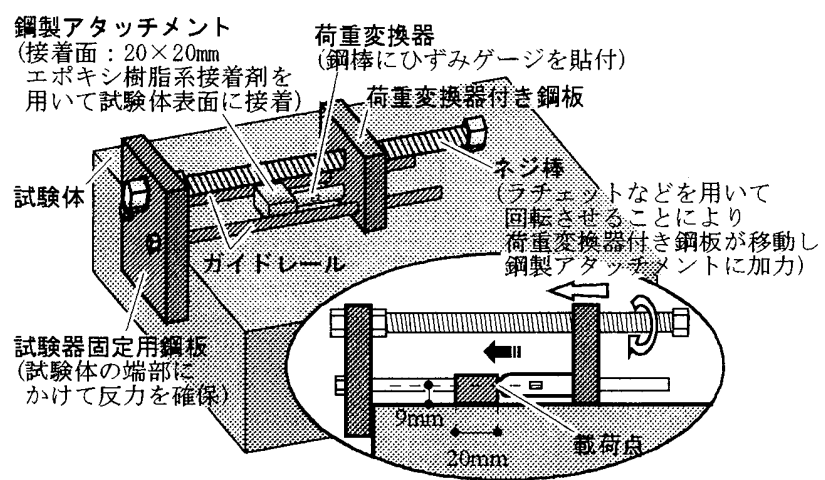

図2 せん断強度試験器の概要

卜を床下地表面に接着したうえで、同試験器を用いて垂直方向に引っ 張り、アタッチメントが床下地から剥離するまでの荷重の最大值を 測定し、これを接着面の面積で除した值を引張強度として求める。

\section{(3) せん断強度}

筆者らが製作したせん断強度試験器2゙を用いる方法。図2に、せん 断強度試験器の概要を示す。この試験器は、鋼製アタッチメントを 床下地表面に接着したうえで、ネジ棒を回転させることにより水平 方向に加力し、その時の荷重を荷重変換器 (圧子となる鋼棒に貼付し たひずみゲージ)で測定するものである。この試験器を用い、20×20m のアタッチメントが床下地から剥離するまでの荷重の最大值を測定 し、これを接着面積で除した值をせん断強度として求める。

\section{II 表層部の水分量}

\section{（1）水分計指示值}

I の(1)で述べた「測定方法，グレード8)」に、水分量(表面から $40 \mathrm{~mm}$ 程度まで)の測定方法として規定された方法。コンクリート，モルタル 用高周波静電容量式水分計を用いる方法で、この水分計老床下地上 に置き、表示值を読みとる。表示值は、大きいほど水分量が多いこと を表す。ただし、この表示值は、真の含水率を直接表すものではない。

\section{III 表層部の密実性}

\section{（1）水位低下量}

表層部の密実性は、表面強度に影響するほか、SL材施工前に塗布 するプライマーの効果に影響する可能性があると予想される。すな わち、十分な密実性を有する床下地では、塗布したプライマーが表 面にとどまり徐々に溶剤(水)が蒸発することにより塗膜が形成され るのに対し、密実でない床下地では、プライマーが床下地に吸収さ れ表面に塗膜が形成されないものと予想される。よって、表層部の

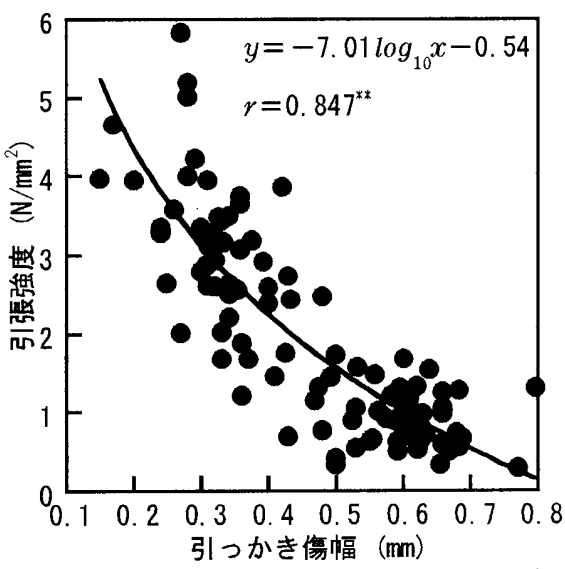

図中の回帰式の $x$ は横軸、 $y$ は縦軸の值を表す

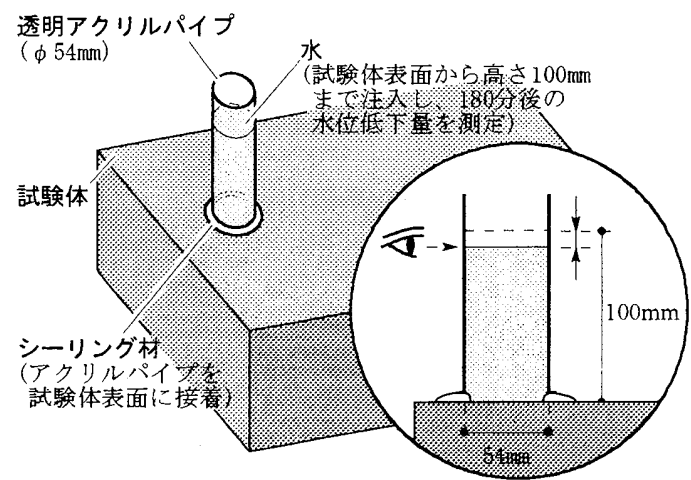

図3 水位低下量の測定概要

密実性を吸水度合いを用いて把握することとし、以下に示す方法で 水位低下量を測定寸ることとした。

図3に、水位低下量の測定概要を示寸。本測定は、透明アクリルパ イプをシーリング材を用いて床下地表面に垂直に接着し、水を注入 したうえで一定時間経過後の水位の低下量を測定するものである。 なお、水位の測定時間やアクリルパイプの底面直径は、数十種の床 下地を用いた予備実験の結果に基づいて設定した。具体的には、底 面直径が $31 \mathrm{~mm}$ と $54 \mathrm{~mm}$ の種のアクリルパイプを用い、注水後5〜10分 ごとに水位の低下量を測定した。その結果、水位低下量からみた試 験体の序列は、注水後 120 分程度までは入れ替わりがあるが以降は比 較的安定しているこ上、拉よび底面直径により大きくは変化しない ことが明らかとなったことから、現在使用されているSL材の多くが 施工後約 3 時間で上に乗って軽作業が可能な程度まで硬化すること、 拉よび底面直径が $31 \mathrm{~mm} の$ 場合床下地の細かい凹凸の影響でアクリル パイプが正常に接着しにくい場合があったことなども勘案し、180分， $54 \mathrm{~mm}$ とした。

\section{IV 表面凹凸}

\section{（1）表面凹凸波形}

筆者らが既往の研究つで製作，使用した、水平に設置した直定規 上でレーザ変位計をスライドさせる表面凹凸測定装置を用い、休下 地表面に設定した測定線上の凹凸を2次元の波形として把握寸る。

\section{2. 測定経调}

表層部品質の測定は、SL材の施工3日前から前日にかけて実施した。 引っかき傷幅, 引張強度, 广ん断強度, 水分計指示值, 水位低下 量の測定は、試験体のうち表層部品質の測定に供することとした 600 $\times 200 \mathrm{~mm}$ の部分 (図1参照)をさらに半分 $(300 \times 200 \mathrm{~mm})$ に区切り、その

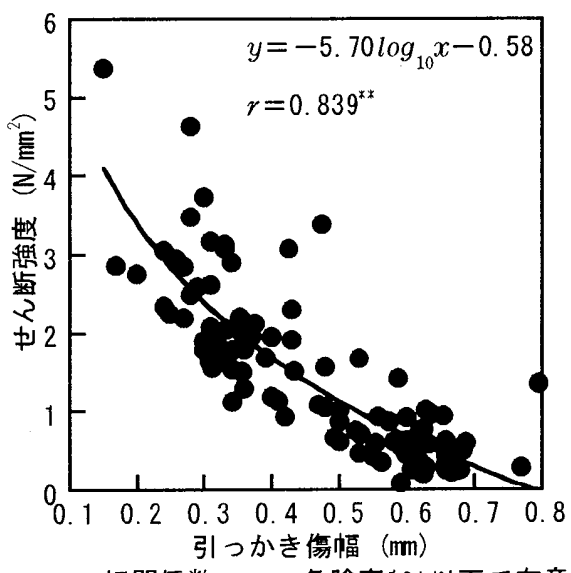

$r:$ 相関係数 **: 危険率 $1 \%$ 以下で有意 せん断強度の関係 


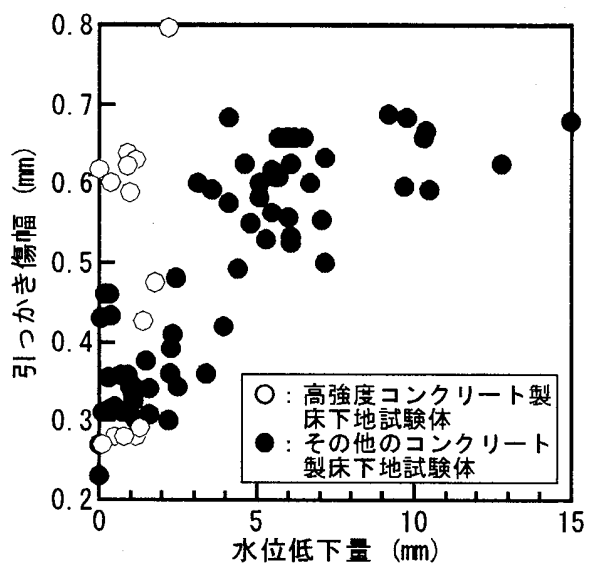

図5引っかき侔幅と水位低下量の関係

一方で実施した。なお、もう一方は、予備とし て保存しておくこととした。引っかき傷幅の測 定にはL社製引っかき試験器、引張強度の測定 にはY社製建研式接着力試験器LPT-1500、水分 計指示值の測定にはKT社製コンクリート，モルタル用高周波静電容 量式水分計HI-520を用いた。測定回数は各測定項目とも 3 回以上とし、 結果が安定していることを確認したうえで、平均を求めた。

一方、表面凹凸の測定では、図1に示寸ように試験体中央を中心に $100 \mathrm{~mm}$ 間隔で5本の測定線を設定し、各測定線上の凹凸を測定した。 測定には、KY社製レーザ変位計LK-500を用いた。

\section{3. 測定結果および考察}

図4に、引っかき傷幅と引張強度，せん断強度の関係を示す。図に は、前報(その 2 )で用いた試験体での測定結果もあわせてプロット してある。また、㘠には、回帰曲線と回帰式、抒よび相関係数も示 した。図に示す通り、いずれの図でも両者はよい対応を示しており、 相関倸数も危険率 $1 \%$ 以下で有意となっていることから、本報の結果 を追加しても、前報(その 2 ) までの結果と同様、3種の方法による測 定結果には互いに高い相関があることがわかる。

図5に、引っかき傷幅と水位低下量の関保を示す。図より、全体的 にみると両者は比較的よい詨忘を示しており、表層部の密実性は表 面強度と密接に関倸している8 ことが確認できる。しかし、詳細に みると、図中○で示した高強度コンクリート製床下地試験体による 点の一部が、密実性が大きい割に表面強度が小さくなっていること がわかる。この理由として、セメントの種類や水セメント比、执よ び単位水量, 単位セメント量などの影響で、セメント水和物中の細 孔構造や表層部に占めるセメント水和物の割合などに違いが生じて いることなどが考えられるが、詳細な険討は今後の課題とする。

図6に、表面凹凸の測定結果の例を示寸。図の(1)は比較的凹凸が 小さい試験体で測定された波形の例、(2)は大きい試験体で測定され た波形の例を示したものである。これらの波形から、試験体ごとに、 最も高い位置と低い位置の差(最大高低差)を求名とともに、波形 を1 mm間隔でサンプリングし、その標準偏差を求めた。表2に、全試

表3 SL材の概要

\begin{tabular}{|c|c|c|c|c|c|}
\hline \multirow[b]{2}{*}{ 分頪 } & \multirow[b]{2}{*}{$\begin{array}{l}70-- \\
(\mathrm{cm})\end{array}$} & \multirow[b]{2}{*}{$\begin{array}{l}\text { 強度 } \\
\left(\mathrm{N} / \mathrm{m}^{2}\right)\end{array}$} & \multirow[b]{2}{*}{ 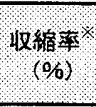 } & \multicolumn{2}{|c|}{ アライマー } \\
\hline & & & & 主成分 & $\begin{array}{c}\text { 嫩準浲布量 } \\
\left(\mathrm{g} / \mathrm{m}^{2}\right)\end{array}$ \\
\hline セメント系 & 22 & 25 & 0.08 & アクリル酸エステル & $\begin{array}{l}\text { 1回目: } 200 \\
\text { 2回目 : } 100\end{array}$ \\
\hline
\end{tabular}

※ 材芧28日(4週)での值
験体の最大高低差および標準偏差の範囲を示す。表に示寸通り、最 大高低差，標準偏差の範囲は、前報（その1）で表面凹凸の影響でひ び割れが発生した試験体の最大高低差, 標準偏差を大きく下回って おり、かっ不具合の発生に表面凹凸の影響がみられなかった試験体 の範囲と比較しても同程度以下であることから、本報で用いた試験 体のなかにひび割れの発生に影響寸るような表面凹凸が極端に大き いものはないことが確認できる。

\section{SL材の施エおよび不具合の記録，浿定}

\subsection{SL材の施工}

6. で表層部品質を測定した試験体の $600 \times 600 \mathrm{~mm}$ の部分 (図1参照) に、SL材を施工した。ここで、使用寸るSL材やSL材の施工方法(塗 り厚および施工手順など)は、前報(その2) と同一とした。表3に、 SL材の概要を示寸。SL材は、セメント系の一般的なもので、市販の 袋詰め既調合粉体を購入し、実験室で水と混練後所定の流動性を確 認したうえで施工した。SL材の塗り厚は、使用したSL材で推奨され ている $20 \mathrm{~mm}$ (平均厚さ) とした。また、SL材施工前に床下地表面に塗 布するプライマーは、SL材に指定されたものを標準量用いることと し、塗布回数は、SL材に規定された2回とした。

SL材の施工は、2005年6月，8月および2006年3月，7月に4回に分 けて実施した。はじめに、プライマいを刷毛で塗布し乾燥させる作 業を、SL材施工前日上当日の2回実施した。続いて、2回目のプライ マー塗布から4〜5時間以上経過後、SL材を施工した。SL材は、試験 体の面積と平均厚さから算定される必要量を計量, 混練し、床下地 上に流し込んだうえで、金ごてを用いて流し延べる工法で施工した。 作業は、熟練したSL材施工作業担当者の指導のもと、日常はSL材の 施工作業に従事していない者が行った。特に、金ごてで流し延心゙る 作業は、作業者の違いによる影響排除寸る目的で、全て同一の者 が行った。

なお、SL材の施工と同時に、「JIS A 1129-2 モルタル及びコン クリートの長さ変化試験方法第2部：コンタクトゲージ方法にに準じ た方法でSL材の収縮率を測定寸るための供試体 $(40 \times 40 \times 160 \mathrm{~mm})$ を 3 個づつ計12個作製し、試験体と同一の実験室内に存置した。 


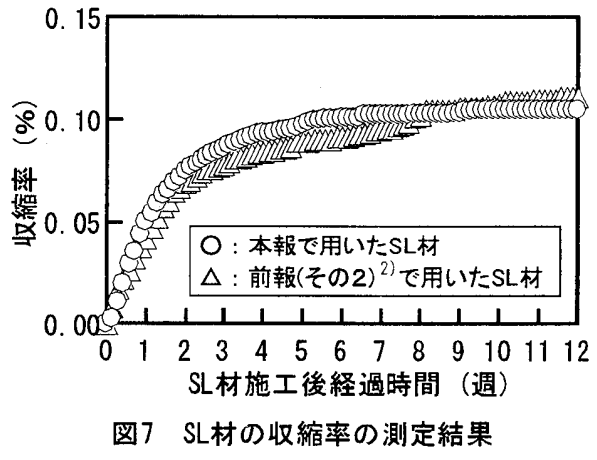

\section{2. SL材の塗り厚の測定}

SL材の塗り厚を確認する目的で、硬化後に、6.1.で述べたと同様 の方法で、図1に示した測定線と同一位置のSL材の表面回凸波形を 測定した。图6に、測定結果の例を示寸。こ礼らの波形と6.で測定し た床下地の表面凹凸波形との差から、SL材の塗り厚の最大值(最大 㳂り厚)，最小值(最小㓌り厚)を求めるとともに、波形を $1 \mathrm{~mm}$ 間隔で サンプリングして各点での塗り厚を求め、その標隻偏差を求めた。

表2に、全武験体の最大叙り厚，最小叙り厚および標準偏差の筈囲を 示寸。表上り、6.3.で述べたと同様の理由から、本報で用いた試験 体のなかにひび割れの発生に影響するような㙦り厚が著しく薄い(厚 い部分や塗り厚の変化が著しく大きい部分があるものはないことが 確認できる。

\subsection{SL村の收縮率の測定}

7.1. で作製した供試体を用い、SL材の収縮率を施工後 1 ～ 2 日間隔 で測定した。図7に、測定結果を示す。図は、12個の供試体での測定 結果の平均を示したものである。また、図には、同一のSL材を用い た前報(その2)での測定結果もあわせて示した。図より、収縮率は 施工直後に急激に増加寸るがその後増加の度合いは低下し最終的に $0.11 \%$ 程度に収束すること、およびこの結果は前報(その 2 ) での結 果とほぼ一致していることがわかる。

\subsection{SL材の不具合の記録, 测定}

\subsection{1 記録, 湘定概要}

7.1. で施工したSL材の不具合の発生状況を、施工後7日 (1週)ごと に記録した。具体的には、透明フィルムをSL材上に敷きサインペン でひび割れを写し取るとともに、ひび割れごとに目盛付自在曲線定 規を用いて長さを測定し、クラックスケールを用いて平均的な幅を 測定した。対象とするひび割れは、肉眼でも容易に判断できる幅 $0.05 \mathrm{~mm}$ 以のひび割れとした。また、打音棒でSL材上を打撃し、健 全な部分とは明らかに音色が異なり剥離しているとみなせる部分を、 上述のひび割れを記録した透明フィルム上に重ねて記録した。

記録, 測定は、SL材施工12週後にひび割れおよび剥離の発生, 成 長がほぼ止まったとみなせたことから、終了した。

\subsection{2 記録，測定結果および考察}

図8に、SL材施工1週後，4週後，12週後のひび割れおよび剥離の 発生状況の例を示す。図中のひび割れを示す線の太さは、前報(その 1 )で得られた知見に基づいて、ひび割れの幅に応じて $0.2 \mathrm{~mm} 末$ 満之 $0.2 \mathrm{~mm}$ 以上の 2 種に分類している。

図に例示寸るように、SL材のひび割れおよび剥離の発生状況は床 下地により大きく異なっており、各試験体をひび割れ，剥離の発生 状況に基づいて、以下の3種に分類することができる。

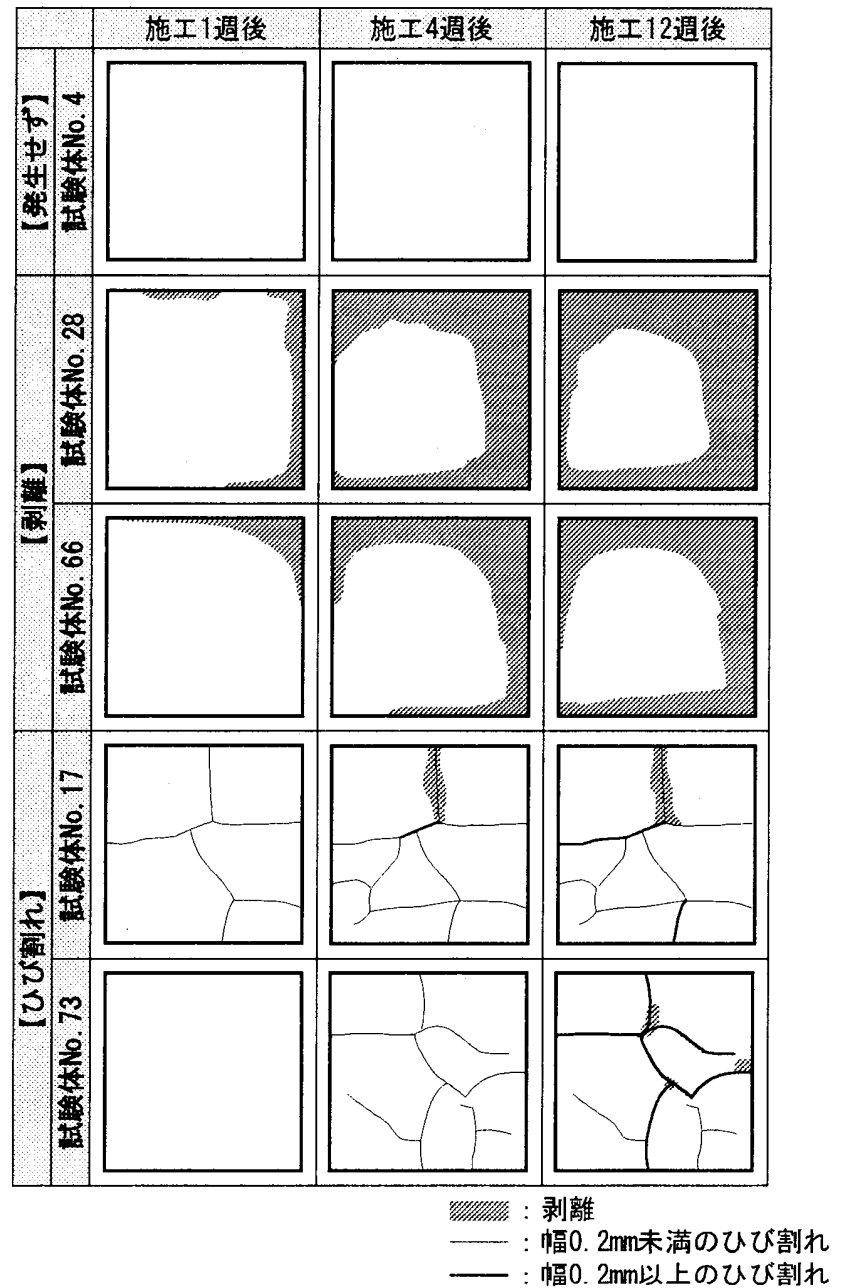

図8 SL材の不具合の発生状況の例

【発生せず】: ひび割れ，剥離が発生していない試験体。

【剥離】：SL材施工1週後程度で周囲から早期剥離が発生している試 験体。これらの試験体では、ひび割れはほとんど発生しないか、 発生してもその程度は比較的小さい。

【ひび割れ】：早期剥離は発生しないが、SL材施工4週後程度までに ひび割れが発生している試験体。これらの試験体では、以降も SL材施工12週後程度まで発生したひび割れの幅が増加する。さ らに、ひび割れに沿って剥離が発生する場合がある。剥離は、 ひび割れの幅が大きい( $0.2 \mathrm{~mm}$ 程度以上) 箇所ほど発生しや寸い。

各試験体を分類した結果を、表にに示す。なお、不具合が発生した 試験体を発生状況から【剥離】と【ひび割れ】の2種に分類できる点 は、前報(その1)の結果と一致している。また、【ひび割れ】に分類 した試験体でのひび割れの発生時期やその後の幅の増加傾向などは、 前報(その 1 )および(その 2 )の結果と一致している。

ここで、これらの不具合の発生状況の違いは、SL材と床下地の接 着の程度の差に起因するものと予想される。すなわち、接着力が十 分な場合はSL材の収縮が拘束されるため不具合が発生しないのに対 し、接着力が若干不足する場合は、部分的にSL材の収縮を拘束でき ない箇所が存在しその箇所でひび割れが発生する。一方、より接着 力が低い場合は上記のひび割れより先に剥離が発生寸るが、剥離発 生後はSL材の収縮が拘束されないため、大きなひび割れは発生しな いものと考えられる。 


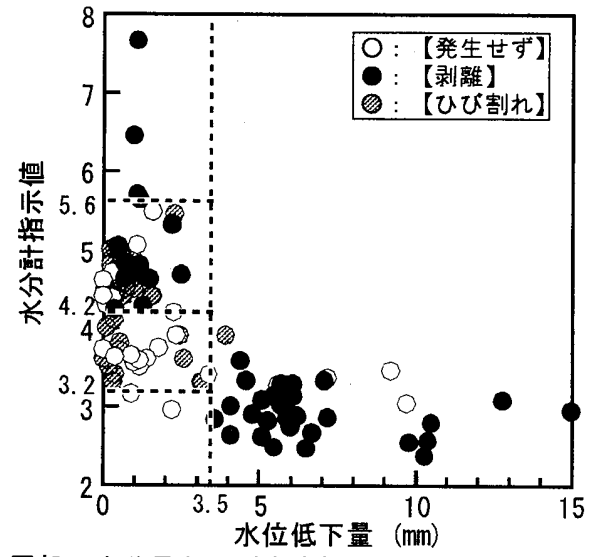

図9 表層部の水分量および密実性と不具合の発生状況の関係

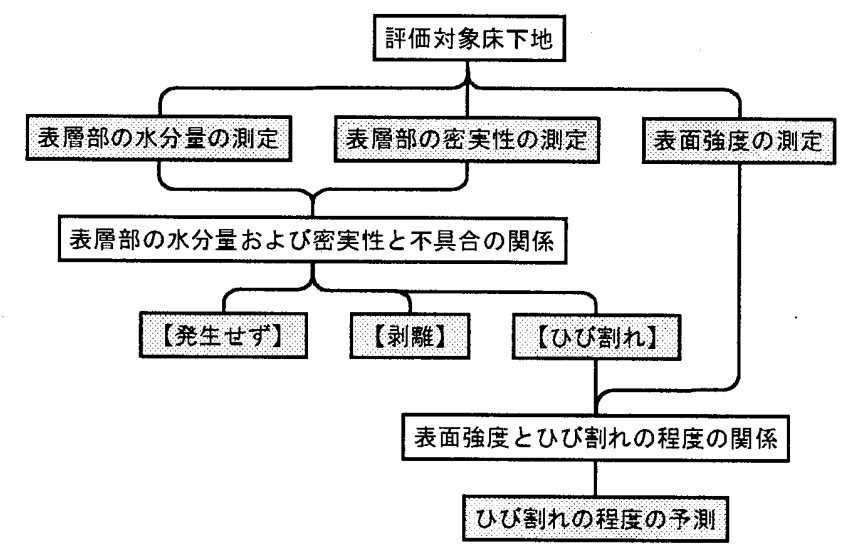

図11SL材の不具合の予測方法
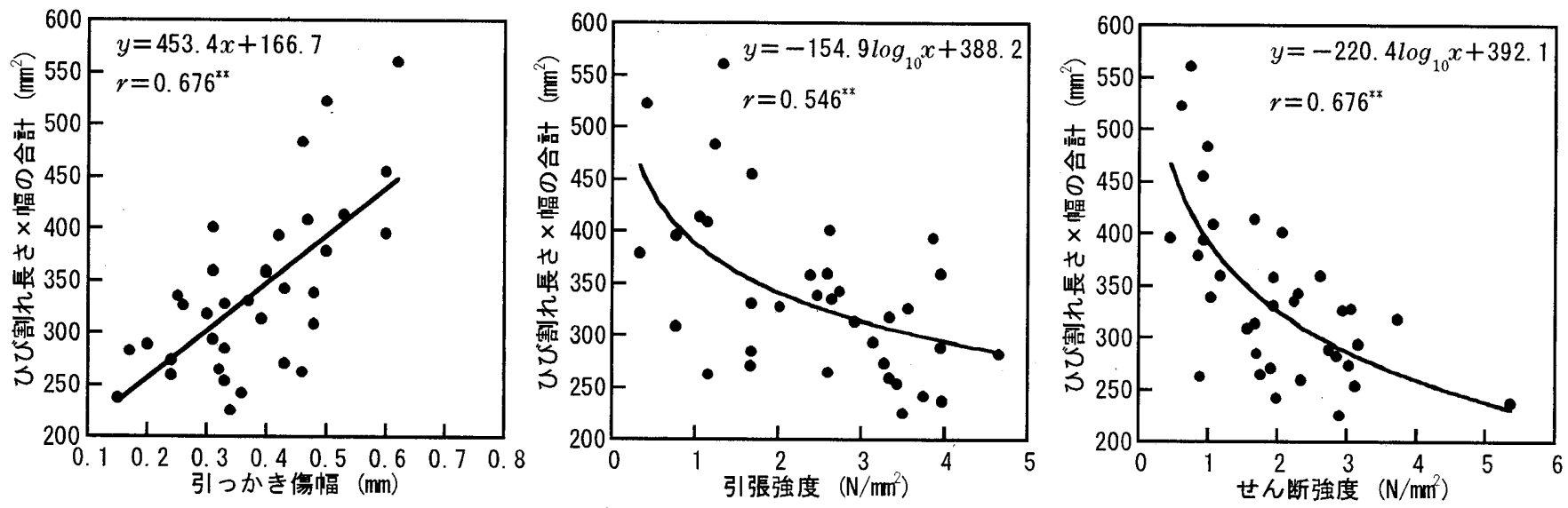

図中の回帰式の $x$ は横軸、 $y$ は縱軸の值を表す $\quad r$ : 相関係数 $* *$ : 危険率 $1 \%$ 以下で有意

図10 ひび割れ長さ $\times$ 幅と引つかき傷幅，引張強度，せん断強度の関係

\section{8. 床下地の表層部品筫とSL材の不具合の関係の検討}

\section{1. 表層部の水分量，密実性と不具合の関係の検討}

図9に、表層部の水分量および密実性と不具合の発生状況の関係を 示寸。図は、各試験体の水分計指示値, 水位低下量を、不具合の発 生状況に応じて記号を変えてプロットしたものである。また、図に は、SL材の種類, 塗り厚などの条件が同一の前報(その 2)の結果も あわせてプロットしてある。ここで、前報(その 2 ) で用いた試験体 の不具合の発生状況は、いずれも【ひび割れ】に分類される。

図より、水位低下量がある值を超えると、不具合の発生状況が【剥 離】となる可能性が著しく高くなっていることがわかる。これは、6.1. の正で述べた通り、密実でない床下地ではプライマーが床下地に吸 収されることによるものと思われる。すなわち、このような床下地 では本来プライマーの塗布量を多くする必要があるが、本報では塗 布量を試験体の違いによらず一定としたため、密実性の小さい試験 体でプライマーが不足し、表面に塗膜が適切に形成されなかったこ とが考えられる。なお、本報で用いたSL材の種類および塗り厚など の条件では、【剥離】とならないための水位低下量の上限は $3.5 \mathrm{~mm}$ 程 度とみなすことができる。

一方、図より、水位低下量が上記の值を下回っている場合は、水 分計指示值に応じて不具合の発生状況が変化していることがわかる。 すなわち、水分計指示值が小さい場合は【発生せず】となる可能性 が高いが、大きくなるにしたがって徐々に【ひび割れ】となる可能 性が高くなり、さらに大きくなると【剥離】となる可能性が高くなっ ていることがわかる。この理由として、床下地の水分量が大きいほ
ビ、水分の影響でプライマーの塗膜が正常に形成されないため接着 不良の度合いが大きくなり、施工直後に急激に增加寸るSL材の収縮 を拘束できず、【ひび割れ】、【剥離】と段階的に不具合が発生した ことが考えられる。なお、本報で用いたSL材の種類および塗り厚な どの条件では、水分計指示值が 3.2 程度を超える上【ひび割れ】上な る試験体が現れはじめ、4.2程度を超えると【剥離】となる試験体が 現れはじめた。さらに、5.6程度を超えるといずれの試験体でも【剥 離】となった。

\section{2. 表面強度とひび割れの程度の関係の検討}

7.4.2で【ひび割れ】に分類した試験体を対象に、ひび割れの程度 と表面強度の関係を検討した。図10に、ひび割れ長さメ幅と引っか き傷幅, 引張強度, せん断强度の関係を示寸。図には、前報(その2) で用いた試験体での測定結果もあわせてプロットしてある。また、 図には、回帰曲線上回帰式、および相関倸数も示した。

図に示す通り、いずれの図でも両者は比較的よい対応を示してお り、相関係数も危険率 $1 \%$ 以下で有意となっていることから、本報の 結果を追加しても、前報(その 2)の結果と同様、SL材のひび割れの 程度と床下地の表面強度には高い相関があり、表面強度が小さいほ どひび割れの程度は大きくなることがわかる。この理由として、水 分量の影響でSL材施工4週後程度までにひび割れが発生した試験体 では、その箇所にSL材の収縮による応力が集中するが、床下地の表 面強度が小さいほ上゙集中寸る応力により表面が破壊されや寸いため、 収縮が拘束されずひび割れ幅が増大したことが考えられる。 


\section{SL材の不具合の予睤方法の枠組みの提示}

8. までの検討結果に基づき、SL材の不具合の予測方法の枠組みを、 以下の通り提示寸る。

(1) 評価対象床下地で、表層部の水分量, 密実性および表面強度を測 定する。

(2) (1)で測定した表層部の水分量および密害性から、不具合の発生状 況が【発生せず】【剥離】、【ひび割れ】のいずれになるかを予 測する。

(3) (2)で【ひび割れ】と予測された場合は、(1)で測定した表面強度か ら、ひび割れの程度を予測する。

以上に述べた予測方法の流れを、図11に示す。

なお、(1)で測定する表面強度の測定方法は、本研究で採りあげた 3 種 の方法のなかでは、測定の簡便さや測定痕の処理の容易さなどを考 慮すると、引っかき試験器法が見段階では最も実用性が高いと考え る。

\section{0. おわりに}

様々な種類のコンクリート製床下地の表層部品質とSL材に発生寸 る不具合との関係を実験的に検討したうえで、前報（その 2 )の結果 とあわせ、種々のコンクリート床下地に共通に適用できるSL材の不 具合の予測方法の枠組みを提示した。本報の結論をまとめると、以 下の通りである。

（1）様々な種類のコンクリートを用いて床下地試験体を作製し、表 層部品質を測定した。その結果、3種の方法での表面強度の測定 結果 (日本建築仕上学会式引っかき試験器法, 建研式接着力試験 器法およびせん断強度試験器を用いる方法)には互いに高い相関 があるこ上が確認できた。また、表面強度と表層部の密実性と の関倸を検捨した結果、高強度コンクリート製床下地のなかに は、他のコンクリート製床下地と比較して密実性が大きい割に 表面強度が小さいものがあることがわかった。

（2）床下地試験体にSL材を施工し、発生する不具合を記録，測定し た。SL材の不具合の発生状況は床下地により大きく異なってお り、【発生せず】，【剥離】、【ひび割れ】の3種に分類することが できた。

（3）表層部の水分量および密実性と不具合の発生状況の関倸を検討 した。その結果、密実性がある程度以上小さいと、【剥離】とな る可能性が著しく高くなることがわかった。また、密実性が十 分な場合、水分量に匛じて不具合の発生状況が変化し、水分量 が小さい場合は【発生せず】となる可能性が高いが、大きくな るにしたがって徐々に【ひび割れ】となる可能性が高くなり、 さらに大きくなると【剥離】となる可能性が高くなることがわ かった。

（4）【ひび割れ】に分類した試験体を対象に、表面強度とひび割れ の程度の関係を検討した。その結果、両者には高い相関があり、 表面強度が小さいほどひび割れの程度は大きくなることがわ かった。

（5）（2＜wide>（4）の検討結果をまとめ、SL材の不具合の予測方法の枠組 み提示した。
以上であるが、本報で示したSL材の不具合之床下地の表層部品質 の関係における絶対值は、あくまでもSL材の種類および塗り厚なよ゙ の条件を限定した実験で得られた一例である。今後は、これらの条 件を多様にし、収縮率などに基づいて絶対値の変化の傾向を把握し てゆく必要があると考える。また、実際の建築物でのSL材の不具合 と床下地の表層部品質の関倸などについて険討を重齐、より汎用性, 一般性の高い予測方法の提示を試みる予定である。

\section{謝辞}

本研究のテーマ設定や方向付けなどにあたり種々御指導いただい た小野英哲先生 (東北工業大学教授, 東京工業大学名誉教授・工博) に、厚く御礼申し上げます。また、本研究に対し有益な御助言老い ただくとともに実験に多大な御協力をいただきました筒井清光部会 長, 堤 豊前幹事, 大野晴巳幹事をはじめとする日本建築仕上材工業 会SL材部会の皆様、および梶浦茂男第一部会長をはじめとする日本 床施工技術研究協議会注1)第一，二部会の皆様に、厚く御礼申し上げ ます。

\section{注}

注1）日本床施工技術研究協議会（会長：小俣一夫）：床施工に関する技術を調 查，研究することを目的に平成6年に設立された任意団体で、主たる床 関係工業会が法人会員、床関保技術者, 研究者が個人会員の、平成 18 年 12月現在会員数約60の協議会

\section{参考文献}

1）横山裕，金 兒鎬，横井 健，崔 寿灵：SL材に発生するひび割れの観察扝 よび武験体の大きさの影響に関する検討，SL材のひび割れからみたコンク リート床下地の表層部品質の評価方法 (その1)，日本建築学会構造䒺論文 集，第605号，pp.9-16，2006.7

2）横山 裕，金 兒鎬，横井 健，崔 寿灵：高強度コンクリートを対象とした 床下地の表面強度とSL材のひび割れの関倸に関する基整的検討，SL材のひ び割れからみたコンクリート床下地の表層部品質の評価方法（その 2 )，日 本建筑学会構造系論文集，第610号，pp. 13-20，2006. 12

3）横山 裕, 横井 健 : コンクリート床下地の凸凸に関する指標の具体例の提 示，日本建築学会構造系論文集，第609号，pp. 15-22，2006.11

4）横山裕, 横井健：高強度コンクリートの朱上面仕上げ作業のしやすさお よび完成後の品質に関する基礎的研究, 日本建築学会大会学術講演梗概集, A-1, pp. 1067-1068, 2002.8

5）横山 裕，横井 健：コンクリート床下地の表層部品質に関する指標のあり 方，日本建築学会構造系論文集，第580号，pp. 15-22，2004.6

6）小野英哲, 横山裕, 永橋 進, 楃浦茂男、横井 健, 湯浅 昇, 端 直人, 小俣一夫：コンクリート床下地表層部の諸品質の簡易測定,評価方法の提 案，日本建築学会技術報告集，第18号，pp. 11-16，2003.12

7）横山裕，西谷伸介：コンクリート床下地の施工労力と床の品質㧍よび保 全労力に関する実験的研究， 日本建築学会構造系論文集，第 584 号, pp. 29 $-36,2004.10$

8）横山 裕, 森 剛平, 横井 健: コンクリート床の品質とフレッシュコンク リートの特性拉よび施工条件の関係，その 4 表面強度㧍よび水分量の観 点からの検討，日本建築学会大会学術講演梗概集，A-1，pp.631-632，2003.9

（2006年12月10日原稿受理，2007年 2 月 1 日採用決定） 